\title{
COMMENTS
}

\section{THE OBLIGATION OF A HIGH-LEVEL EMPLOYEE TO HIS FORMER EMPLOYER: THE STAYDARD BRANDS CASE}

In the context of the modern corporate world, the lack of human perfection has necessitated the development of judicial1 and legislative 2 standards of behavior which impose upon an employee-fiduciary "the duty of so disciplining [his] acquisitive impulses that they will operate vicariously so as to increase to the maximum extent possible not [his] own acquisitions but those of [his] employer. ": This fiduciary duty is not a concept taken lightly by the courts. + This comment. however, is not concerned with the fiduciary relationship in general. Rather it deals with the scope of permissible behavior of a high-level or executive employee when he formulates plans to compete with his employer prior to the termination of his employment relationship.

While the courts often speak of the duties of such an employee in terms of the fiduciary requirements of a corporate director or business partner, 5 there is probably a valid distinction between cases involving these two classes of fiduciaries. A suit for unfair competition against a former employee will usually be concerned with acts leading up to a sharp break with the employer, coupled with the formation of a separate competing enterprise. A suit against a director for breach of fiduciary duty will usually be concerned with his

1 "The policy of the law is to put fiduciaries beyond the reach of temptation by making it unprofitable for them to yield to it." Hoyte v. Hampe, 206 Iora 206, 220, 214 N.W. 718, 724-25 (1927).

: See, e.g., ILI. REv. STAT. ch. 98, §§ 234-35, 237-45 (1935).

3 Dodd, Is Effective Enforcement of the Fiduciary Duties of Corporate Managers Practicable? 2 U. CHI. L. REv. 194, 195 (1935).

4 "[A]n agent is subject to a duty to his principal to act solely for the benefit of the principal in all matters connected with his agency." 2 RESTATEMENT (SECOND), AGENCY $\$ 387$ (1957). "[The] relationship . . was one in which the most perfect good faith was required, -a relationship uterrima fides." Hunter v. Shell Oil Co., 198 F.2d 485, 489 (5th Cir. 1952); "its paramount and vital principle is good faith; $u$ ithout it the relationship of principal and agent cannot exist; and so sedulously is thus principle guarded, that all departures from it are esteemed frauds upon the confidence bestoried." Keighler v. Savage Mfg. Co., 12 Md. 383, 416 (1858); accord, Nagel v. Todd. 185 Md. 512, 517, 45 A.2d 326, 328 (1946); see Guth v. Loft, 23 Del. Ch. 255, 268-83, 5 A.2d 503, 509-15 (1939); cf. State ex rel. Harris v Gautier, 108 Fla. 390,147 So. 240 (1933); Bank of California v. Hoffman, 255 Wis. 165, 171, 30 X.W.2d 506, 509 (1949); see generally LATTY, INTRODLCTION To BusINESS AssoctATIONS; 381-83 (1951); 1 MECHEM, AGENCY \$\$ 1188-1239 (2d. ed. 1914); TIFAANY, AGENCY $\S \S 142-47$ (2d ed. Powell 1924); Ballantine, Morbid Morality: A Standard for Galahad or "Reasonable .Men"? 38 A.B.A.J. 298 (1952); Dodd, supra note 3; Evans, Fiduciary Obligations of Agents, 2 W. REs. L. REv. 5 (1950); Note, 54 HARV. L. REv. 1191 (1941).

s See, e.g., Hunter v. Shell Oil Co., supra note 4. 
usurpation of a corporate opportunity while the relationship is still maintained with the principal. ${ }^{6}$ This seemingly insignificant difierence is actually quite important in that an employee, even one high in a corporate hierachy, is for the most part dependent on his employment for his means of subsistence. This is not likely to be the case with a director, where the income, if any, from the directorship is probably ancillary to the individual's main source of remuneration. Consequently, the holding of an employee to the fiduciary level of a director is likely to result in considerable financial hardship, particularly if he is enjoined from competing with his former employer.?

Similarly, cases involving high-level employees can be distinguished from those involving employees in the lower levels of a corporate or business hierarchy. 8 The main difference is that since "varying degrees [of] trust and confidence are reposed, and are expected to be reposed, in the representative,"9 it would seem logical that the degree of trust and confidence will vary with the position of the individual. Hence, a non-executive employee will usually be held to a lower standard than is an executive employee, just as an executive employee will usually be held to a lower standard than is a director. ${ }^{10}$

Two cases in which there has been judicial concern with the conduct of high-level employees in regard to competitive preparations are Standard Brands, Inc. v. United States Partition Corp.11 and Duane Jones Co. v. Burke.12 These two cases appear to be illustrative of the relatively few decisions in this area. Since they involve varied and intricate factual situations, the two cases tend to exemplify the range of problems that can arise. 13 It must, however, be remembered that there are likely to be special problems and developments within a particular jurisdiction. 14

In the recent Standard Brands case, particular attention was directed to the effect of the employee's competitive preparations on the intangible corporate

6 See, e.g., Guth v. Loft, 23 Del. Ch. 255, 5 A.2d 503 (1939); Meinhard v. Salmon, 249 N.Y. 458, 164 N.E. 545 (1928).

7 An injunction is the form of relief usually sought in these cases. See 2 RESTATEMENT (SECOND), AGENCY $\S 399$, comment on clause (f) at 233 (1957); see also McClain, Injunctive Relief Against Employees Using Confidential Information, 23 KY. L. J. 248 (1935). See note 68 infra.

8 These cases will be discussed more thoroughly infra note 50.

9 LATTY, op. cit. supra note 4, at 381. (Emphasis added.)

10 See text accompanying note 7 supra.

11130 U.S.P.Q. 258 (E.D. Wis. 1961).

12281 App. Div. 662, 121 N.Y.S.2d 107 (1953), aff'd as modified, 306 N.Y. 172, 117 N.E.2d 237 (1954).

13 For other cases of a similar nature see note 43 infra.

14 For a particularly cogent discussion of the status of the law in California, see Hays, The California Law of Unfair Competition Takes a Turn-Against the Employer, 41 CalfF. L. Rev. 38 (1953). See also McClain, supra note 7; Note, Protection of Customer Lists in New York, 1 SYRacuse L. Rev. 110 (1949). 
asset of good will.15 In the actual litigation the plaintiff brought an action for unfair competition against four former employees and the corporation which they had organized.16 One of the several allegations against the former key personnel17 was that they had "usurped the good will of [Standard Brands"] customers."18 It was contended that eight months prior to the simultaneous resignation of the three top executives, they had conspired to enter into competition with their then employer, using the corporate defendant as a vehicle for this purpose. With this conspiracy always in mind, they continued to entertain Standard Brands' customers, at considerable expense to the plaintiff, in the hope that "the gifts and entertainment would result in an attitude of good will in the part of the recipient towards [the individual defendants]."19 The plaintiff, therefore, unwittingly financed competition as it naively assumed that the good will flowing from its largess would inure to its own benefit rather than to its employees. Essentially the plaintiff here was contending that the most effective way the corporate entity could develop good will was through the rapport between the defendants, as its representatives, and Standard Brands' customers; and that, since the plaintiff was using the defendants in a manner without the scope of ordinary executive activities, their skills as "gracious hosts" became "personnel assets" of the employer and hence were deserving of judicial protection from abuse. 20 The defendants also copied the plaintiff's blueprints of the machinery necessary for the production of the partitions, thus enabling the corporate defendant to get into production faster at lower costs. Furthermore, they used plaintiff's staff for their own personal benefit while still employed by the plaintiff, and thence proceeded to ask plaintiff's staff to join U.S. Partition when its operations commenced. These acts, especially the attempt to usurp plaintiff's good will, drastically reduced the gross

15 "Good will is not a fixed concept, uniformly understood in the same sense in every type of business. It may relate to a business apart from the personality or reputation of its management or individual owner . . . . A business enjoys various types of good will depending upon the different spheres within which its reputation is established. Good will refers to the business as it is viewed by others." 1 Calmuann, UNFalr Coupeminon and Trade Marks \$2.2 at 21 (1945); see generally Note, An Inquiry Into the Nature of Goodwill, 53 Colus. L. Rev. 660 (1953).

16 The four defendants had been employees of plaintiff's unincorporated division, American Partition Company. The corporate defendant was formed to compete with American "in the business of manufacturing and selling chipboard partitions and other paper product partitions for cases, boxes and containers." 130 U.S.P.Q. at 259.

17 The four defendants had been the president-general manager, vice president in charge of production vice president in charge of sales, and toolroom foreman of American.

18130 U.S.P.Q. at 261.

19 Id. at 265 .

20 "[T]he responsibility of the fiduciary is not limited to a proper regard for the tangible balance sheet assets of the corporation, but includes the dedication of his uncorrupted business judgment for the sole benefit of the corporation ...." Periman v. Feldman, 219 F.2d 173, 176 (2d. Cir. 1955). (Emphasis added.) 
sales of this particular division of Standards Brands.21 The plaintiff requested that the defendants be enjoined from using the duplicated machinery or the parts thereof, and that there be an accounting for profits and general damages. 22

In upholding plaintiff's contention that the continuance of the entertaining, after the formulation of the competitive plans, constituted unfair competition, the court said:

Defendant owed a duty of disclosure after they had formulated their plans. to prepare for engaging in competition. It is not disputed that some customer good will adhered to the immediate dispensers of American's bounty, as shown by the effusive letters of gratitude from the recipients. These activities were wrongful because defendants had not informed American or Standard Brands of their plans to engage in a competitive enterprise and of the steps already undertaken in the accomplishment of their objective. Had plaintiff known of defendants' competitive plans prior to the undertaking of these promotional activities, it would have a choice as to the wisdom of expending considerable sums of money under the circumstances. 23

It is well settled law that (1) a fiduciary is under a duty to disclose to his employer any information, concerning the agency, which the employer would be likely to want to know, 24 and (2) a fiduciary is under a duty, even after

21 The average sales revenue dropped from $\$ 662,400$ in $1954-1956$, to an average revenue of $\$ 40,000$ in $1957-1960$. 130 U.S.P.Q. at 265 .

This division, American Partition Company, was not formed by Standard Brands, but rather had existed in various corporate forms prior to being purchased by the plaintiff. The individual defendants had been employed by American before the consumation of the sale. In letters to plaintiff's customers, written after the termination of their employment, in which they earnestly solicited the customer's patronage, the defendants attempted to justify their behavior with the following explanation:

"Briefly, the reason for the above individuals severing their relations was due to the fact that since Standard Brands acquired American Partition Company, during a period of 16 months of ownership they never once demonstrated or manifested any interest in the human element. There was never any concern or discussions related to the welfare or future of the personnel, individually or collectively. On this basis of day to day insecurity we, individually and collectively, decided that it was time to attempt to build, in some small measure, a future for ourselves in order to attempt to fulfill the monetary and morale [sic] obligations which we as 'individuals' have to ourselves and families." 130 U.S.P.Q. at 265.

22 The amounts recoverable were not computed in the trial court. 130 U.S.P.Q. at 269.

23130 U.S.P.Q. at 267.

24 E.g., Central Ry. Signal Co. v. Longden, 194 F.2d 310 (7th Cir. 1952); Ramey v. Myers, 159 Cal. App. 2d 82, 323 P.2d 805 (Dist. Ct. App. 1958); Bank of California v. Hoffmann, 255 Wis. 165, 38 N.W.2d 506 (1949); Faultersack v. Clintonville Sales Corp., 253 Wis. 432, 34 N.W.2d 682 (1948); see 2 Restatement (SECoND), AgenCY $\$ \$ 381,390$, 392 (1957); 1 MЕCHEM, op. cit. supra note 4, $\S 1207,1353$; TIFFANY, op. cit. supra note 4, $\$ 146(c)$.

RESTATEMENT $\$ 381$ abrogates the requirement of notice when there is a superior duty to a third person not to disclose such information. It is doubtful that the duty to self and family, see note 21 supra, comes within the ambit of this exception. See generally comment (e). 
the termination of the employment, not to use special or confidential matter or knowledge, acquired in the course of the employment, to the detriment of his employer. ${ }^{25}$ Since, however, the employee has rights which cannot be sacrificed to the interests of the employer, 26 the courts must limit what knowledge they will include within the scope of the combined rules.

In Standard Brands, the court held, in effect, that because of the mental state of the defendants while they were entertaining Standard Brand's customers, the rule requiring disclosure of pertinent information to one's employer applied. Hence their failure to disclose their competitive plans and their personal appropriation of plaintiff's promotional activities constituted wrongful behavior. ${ }^{27}$ In granting an accounting for profits and general damages as

2s E.g., Gutleber v. Hahl, 209 N.Y.S.2d 461 (Sup. Ct. 1960); Patterson v. Pollock, 84 Ohio App. 489, 84 N.E.2d 606 (1948); see 2 RestateMENT (SECOND), AGency \$ 396(b) (195T); MEChEM, op. cit. supra note 4, §§ 1209-14; Annot., 165 A.L.R. 1453 (1946). But see cases cited in note 54 infra.

26 See notes 54-56 infra and accompanying text.

27 Since good will is one of the employer's assets, it is not unusual for the courts to protect it. See Callmasx, op. cit. supra note 5, § 2.2; see generally Note, An Inquiry Into the Farure of Good Will, 53 ColtM. L. REV. 660, 666-68, 677-79 (1953). This is particulariy so when the development of the good will has been at considerable expense to the entreprencur. The courts have been willing to protect a firm's customer lists from misuse by a former employee on the assumption that they constituted a vital segment of the business' good will. As was said in California Intelligence Bureau v. Cunnirgham, 83 Cal. App. 2d 197, 203, 188 P.2d 303, 306-07 (1948): "A list of subscribers of a service built up by ingenuity, time, labor and expense of the owner . . . is [the] property of the employer, a part of the good will of his business and, in some instanoes, his entire business. Knowledge of such a list . . may not be used by the employee as his oun property or to his employer's prejudice. It is this urongful use by the former employee $\mathrm{which}$ constitutes an injury to the employer which equity will restrain."

The list protected in Cunningham was a list of fund raising organizations compiled by a firm specializing in the investigation of such organizations. The defendant, a former conployee of the Bureau who had set up a similar service, was enjoined from using the special techniques, information and lists purloined from his former employer. If judicial relief will be granted to an employer under the facts alleged in this case, it is not a major step to protet Standard Brands' financial investment in its promotional activities. Moreover, being high-level employees, a higher degree of fiduciary duty is owed by the defendants in Standard Brands than by an employee in a customer list case. It is academic to distinguish between the costs of investigation in Cunningham and the costs of gifts and entertainment in Standard Brands, where the overall effect is to create the good will necessary for the continuation of the business. It is the behavior of the former employees as it affected the good will, not the substantive difference in good will, which is the concern of this comment. For a discussion of the position of Cunningham in the California law of unfair competition see Hays, supra note 14.

For other case: in which such lists have been proiected because of their developmental costs. see, e.g.. Toun \& Country House \& Home Service, Inc. v. Newberry, 3 N.Y.2d 554, 147 X.E.2d 724, 170 X.Y.S.2d 328 (1958); Halpern v. Berstein, 138 N.Y.S.2d 433 (Sup. Ct. 1955); Witkop \& Holmes Co. v. Boyce, 61 Misc. 126, 112 N.Y. Supp. 874 (Sup. Ct. 1908): Morgan's Home Equip. Co. s. Martucci, 390 Pa. 618, 136 A.2d 838 (1957). But see Arocado Sales Co. v. Wise, 122 Cal. App. 327, 10 P.2d 485 (1932); Eisenstaedt v. Schweitzer, 13 Misc. 2d 703, 177 N.Y.S.2d 277 (Sup. Ct. 1960). See also Corica v. Ragen, 140 F.2d 496 (7th Cir. 1944); Superior Oil s. Renfroe, 67 F. Supp. 277 (W.D. Okla. 1946); Arkansas Dailies v. Dan, 36 Tenn. App. 663, 260 S.W.2d 200 (1953); Ellis, Trade SecreTs $\$ \S 14,74$ (1953). 
well as an injunction against the use of the duplicated machinery, it might well be that the court has created too broad a doctrine in this decision. A rigorous application of the broad holding of Standard Brands will necessarily curtail an employee from developing competitive plans beyond the embryonic stage, at least while he is still in a fiduciary capacity. This will be particularly true in such businesses as advertising agencies, insurance agencies and law firms, where there is a highly developed personal relationship between a representative of the corporation or partnership and the firm's clients. Certainly the opportunities for an employee to ingratiate himself with a client at the firm's expense, would be more prevalent in these areas than was the case in Standard Brands. While the quality of the "product" of these service industries is usually the most important factor, it can be said that to a large extent these professions are predicated on the personal charms of the employees. 28

However, even in its broadest sense, the doctrine of Standard Brands would not impose liability on an employee who terminated his employment as soon as his competitive plans were conceived. The gestation period for the plans would then occur when he was no longer under a fiduciary duty. This seemingly attractive alternative to enterprise killing liability is less impressive, however, when it is realized that only a few people have the liquid financial assets necessary to survive the gestation period without income from wages. Another factor involved here is that an employee would probably prefer his old job to nothing, if, for some reason, there is a miscarriage of his competitive schemes. 29

There are three possible categories of behavior which can be complained of in this area. At one extreme are the cases where the employer is complaining that the employee has been "disloyal" in becoming a competitor of his former employer. It is doubtful that relief will be granted in such a case because of a sub rosa realization by the courts that most businesses must get their start by just such a breaking away. ${ }^{30}$ At the other extreme are the cases where the highlevel employee has stolen a trade secret of his former employer. Judicial relief will definitely be granted under these circumstances. It is the area between these two extremes where the problems arise. If the employee terminates the employment relationship as soon as his plans are conceived, the case clearly falls within the first category. If he decides to stay on, however, the question the courts must decide is whether or not he has exploited the resources of his

28 See LATTY, op. cit. supra note 4 at 402 n.6. In discussing the difficulty of proving that a partner of a law firm has deliberately lined up his clients in order to take them with him when he departed from the firm, the author makes the point that because of the personal element it is questionable whose clients they actually are.

${ }^{29}$ See generally Comment, Permissible Employee Disloyalty and the Duane Jones Case, 22 U. CHI. L. Rev. 278, 287 (1954).

30 Consider, for example, the formation of most law firms and advertising agencies. See note 28 supra. 
employer while preparing for the competitive enterprise. The conduct of the defendants in Standard Brands in regard to the good will and use of the plaintiff's staff can be considered to be within the category of such an exploitation of resources. Of course in this case the conduct also merged with the second eategory since the defendants did copy the blueprints of the machinery.

An analysis of the potential impact of Standard Brands is simplified by viewing it in the light of the earlier Duane Jones decision. In this case, the plaintiff was awarded damages for the loss of customers and personnel, sustained as a result of a conspiracy by several of the individual defendants to form a competing advertising agency. This conspiracy was formulated while the defendants were still in the employ of the plaintiff. The defendants had become dissatisfied with the conditions at the plaintiff agency because of certain "behavior lapses" on the part of its president, Duane Jones. 31 The defendants' concern over the business reverses of the plaintiff prompted them to formulate plans for a new agency. This, however, was only an alternative to buying out Jones' interest in the firm. Jones was forewarned of the alternative plan of the defendants when they attempted to negotiate the purchase. It appeared that Jones was also aware that the defendants had already discussed their inchoate plans with several of the firm's clients, and that these clients had reacted favorably. At the trial, however, there was testimony by Jones to the effect that he had no knowledge that several of the agency's key personnel and clients had been invited to join the new agency, which the defendants had formed subsequent to the failure of the negotiations, but prior to their resignanation. 32 The court held that the conduct of the defendants "as officers, directors or employees of the plaintiff corporation '... fell below the standard required by the law of one acting as an agent or employee of another." "33

31 Thes lapes occurred "at his office, at business functions, and at interviews with actual and prospective customers." 306 N.Y. at $180-81,117$ N.E $2 d$ at 241 . While it is not clear from the opinion, it appears that the "lapses" were due to sloohol. As a rexult of Jooes' conduct in the six months prior to the mass resignation of the individul defendants the agency had lost three major acoounts and had received resignations from certain of its crecutive and staff members. See generally Comment, Termination of the Fudweiary Durty of Burriness Asociates Not to Compete for the Furm's Cusnomers and Suppliers, 4 Dure LJ. 16, 19 (1954); Corment, Permissible Employee Dirloyalty and the Duane Jomes Case, 2 U. CHI. L REV. 278, 279 (1954). For the situation in Standard Brands see note 21 sppra.

32 The credibility of this testimony might well be doubted since it seems reasonable that solicitation woukd be ancillary to the preselling, of which Jones was aware. In fact, it is questionable if thexe two terms have any meaning independent of each other at an.

In Standard Brands it was not clear if the defendants had done any direct solicitation of customer patronage during their entertaining, or if they were retying on the gratitode of the recipients as indirect solicitation.

3306 N.Y. at 187, 117 X.E.2d at 244, quoting from Lamdin v. Broadway Surface Adv. Corp., 272 X.Y. 133, 138, 5 T.E.2d 66, 67 (1936).

There nas no explicit mention that the relief granted to the plaintiff was predicated on the expense to Duane Jones of the firm's detelopment. See generally note 27 supra. However, it would seem logical that there must be some correlation between his efforts, as guiding 
Both Standard Brands and Duane Jones ${ }^{34}$ provide considerable protection to an employer's business interest, by limiting what competitive plans can be made by a high-level employee without his being held liable for unfair competition. In Standard Brands the defendants were held liable because they had not informed their employer of their competitive plans, 35 while in Duane Jones the defendants were held liable even though they had informed their employer of their general competitive plans. ${ }^{36}$ Looking at the two cases together, then, it would seem that the lack of notice is not as important a factor in the determination of liability as the court in Standard Brands considered it to be. Notice was insufficient to prevent liability of the defendants in Duane Jones, and it is doubtful whether mere notice of general competitive plans in Standard Brands would have been sufficient to immunize the defendants from liability. It would also seem unlikely that notice of the copying of the blueprints would have discharged the liability, because the plaintiff could take little solace from such knowledge without the practical relief of an injunction against their use. Only in the rare case where notice might enable the employer to fully protect himself on his own, can notice be said to insulate the employee from liability. In Standard Brands, notice of the competitive plans might only have removed the need for the damage aspect of the relief. 37

spirit of the firm, and its gross advertising billings. If this was the case, the expense might well have been a sub rosa factor in the court's holding of liability.

Because of its equitable nature the cause of action for the wrongful diversion of good will was severed from the case as it was presented to the court of appeals. This difference from the Standard Brands case does not affect its usefulness in interpreting the present state of the law for two reasons. One, it is clear that such a cause of action here would also have been decided adversely to the defendants. Secondly, the conduct of the defendants and not the form of the litigation is important for the purposes of this comment's analysis. See note 68 infra.

34 For discussions of Duane Jones, see generally Comment, Permissible Employee Disloyalty and the Duane Jones Case, 22 U. CHI. L. REv. 278 (1954); Comment. Termination of the Fiduciary Duty of Business Associates Not to Compete for the Firm's Customers and Suppliers, 4 DuKe L.J. 16 (1954); Note, 54 Colum. L. REv. 994 (1954); Comment, 39 IowA L. REv. 185 (1953); Note 38 MiNN. L. Rev. 661 (1954). For the impact of the decision on the advertising industry, see generally, Advertising Age, Jan. 11, 1954 pp. 1, 1A, 75, 79, 82.

35 See text sccompanying note 23 supra. There is, of course, the possibility that notice might have had no effect on Standard Brands' promotional activities. The corporation might well have decided that the cancellation of the policy which they had followed for several years would have been more harmful to its good will than the conspiracy of the defendants. There is also the possibility that the defendants' letters of explanation, see note 21 supra, might have had as much effect on American's business as did the continuance of the entertainment. The court might very well have placed too much stress on the particular conduct of the defendants, while overlooking other ways in which the same end might have been achieved.

${ }^{36}$ It is clear that Duane Jones was aware of the defendants' alternative plan. Since Jones would have to be particularly obtuse in not realizing that there was customer solicitation, it can be argued either that he had such notice, see note 32 supra, or that there was implied notice. See generally Comment, Permissible Employee Disloyalty and the Duane Jones Case, 22 U. CEI. L. REv. 278, 284-85 (1954).

37 But see note 35 supra. 
It seems that some "plus" factor will be required before an employee will be held liable for unfairly competing with his former employer. ${ }^{38}$ The two cases are consistent if the criteria for liability is said to be a "plus" factor of reprehensible behavior. In Standard Brands such a factor would seem to be either the attempt to usurp the plaintiff's good will, the copying of the blueprints for the machinery necessary for the production of the partitions, or the use of the plaintiff's staff by the defendants for their personal benefit. ${ }^{39}$ In Duane Jones the "plus" factor would seem to be the attempt to coerce Jones into selling his interest in the business, the solicitation of customer patronage prior to the termination of the employment, 40 the agency's lack of "equal opportunity" to compete with its former employees, ${ }^{41}$ or the degree of the defendants' appropriation of "corporate opportunities." 42

The need for a "plus" factor does not preclude the possible importance of notice in some circumstances. It is not impossible that in a particular factual context, none of the various acts of an employee preparing for competition individually come within the ambit of reprehensible behavior, but that collectively they do. If it is necessary to look at the sum of the employee's acts, it is possible that lack of notice might "shift the balance" against the employee.43

The need for a "plus" factor of reprehensible behavior seems to support the

38 See 2 Restatement (SECOND), Agency 393 (1957) where, without mentioning a requirement of notice, it is stated that an employee can make certain preparations for competing with his employer prior to the termination of his employment. It would seem that the writers of the Restatement realize that such a requirement would be too onerous a burden on an employee seeking to better himself. See generally note 54 infra and accompanying text. See also, Town \& Country House \& Home Service, Inc. v. Newberry, 3 N.Y.2d 554, 562, 147 N.E.2d 724, 728, 170 N.Y.S.2d 328, 334 (1958).

39 See text accompanying note 21 supra.

40 See text accompanying note 32 supra.

41 See generally Comment, Termination of the Fiduciary Duty of Business Associates Not to Compete for the Firm's Costumers and Suppliers, 4 DUKE L.J. 16 (1954).

42 See generally Comment, Permissible Employee Disloyalty and the Duane Jones Case, 22 U. CHI. L. Rev. 278, 285-86 (1954).

4 For other cases where the degree of reprehensibility of the former employee's behavior, in regard to competitive preparations, appears to be a factor in the determination of whether or not there was liability, see, e.g., Midland-Ross Corp. v. Yokana, 185 F. Supp. 594 (D.N.J. 1960) (appropriation of blueprints, customer lists and cost calculations of a plastic extruding firm); Frank v. Wiltscheck, 115 F. Supp. 28 (S.D.N.Y.), aff'd, 209 F.2d 493 (2d Cir. 1953) (appropriation of service station franchise); Red Top Cab Co. v. Hanchett, 42 F.2d 236 (N.D. Cal. 1931) (use of equipment and facilities for competitive business); Ritterpusch v. Lithographic Plate Service, Inc., 208 Md. 592, 119 A.2d 392 (1956) (solicitation of customers of employer); United Board \& Carton Corp. v. Britting, 63 N.J. Super 517, 164 A.2d 824 (Ch. 1959), aff'd, 61 N.J. Super. 340, 160 A.2d 600 (App. Div. 1960) (solicitation of customers and use of confidential price lists). See also National Welding Equip. Co. v. Hammon Precision Equip. Co., 165 F.Supp. 788 (N.D. Cal. 1958) (use of knowledge of employer's pressure regulator); Mathews Paint Co. v. Seaside Paint \& Lacquer Co., 148 Cal. App. 2d 168, 306 P.2d 113 (1957) (solicitation of customers); State Export Co. v. Mol. Shipping and Trading, Inc., 155 N.Y.S.2d 188 (Sup. Ct. 1959) (appropriation of bicycle franchise). 
thesis that a high-level employee will be held to a lower standard of behavior than a director or a business partner. 44 In cases involving individuals within the highest fiduciary level, the courts have shown less concern with the actual damage to the principal than in proof of a betrayal of the trust imposed. As was said in Guth v. Loft:

The rule [of liability], inveterate and uncompromising in its rigidity, does not rest upon the narrow ground of injury or damage to the corporation resulting from a betrayal of confidence, but upon a broader foundation of a wise public policy that, for the purpose of removing all temptation, extrisuishes all poesibility of profit flowing from a breach of the confidence imposed by the fiduciany relations. 45

In cases involving high-level employees, even if couched in terms of a breach of the fiduciary duty, there is more concern with the injury suffered by the principal as a result of the conduct of the employees. This is true even if the employees are also directors, as was the case in Duane Jones, if the litigation is in the context of their role as employees rather than directors. In effect the high-level employee will not be held to a "punctilio of an honor the most sensitive." 46

However, the high-level employee has a greater duty than a low-level employec. This is manifested by the fact that the courts predicate the protection of an item such as a customer list used by a salesman only upon whether or not it is a trade secret, 17 confidential information ${ }^{48}$ or "property" of the employe. 49 The courts to that the conduct which the former employer ts attempting to impeach must fall within one of the labeled areas before employee liability for unfair competition will be reasonable. 50 This concern for

4 See Guth v. Loft, 23 Del. Ch. 255, 5 A.2d 503 (1939); Meinhard v. Salmon, 249 N.Y. 40,164 N.E. 545 (1920).

423 Del. Ch. at 270, 5 A.2d at 510.

* Meinhard v. Salmon, 249 N.Y. at 464, 164 N.E. at 546.

47 E.g., Bourns v. Edcliff Inatruments, 125 F.Supp. 503 (S.D. Cal. 1954); California Intelligence Bureau v. Cunningtham, 83 Cal. App. 2d 197, 188 P.2d 303 (1948); Avocado Sales Co. v. Wyse, 122 Cal. 344, 10 P.2d 485 (1932); Dairy Dale Co. v. Azevedo, 211 Cal. 344, 295 Pac. 10 (1931); National Tike Board Corp. v. Panelboard Mfg. Co., 27 N.J. Super. 348, 99 A.2d 440 (Ch. 1953); Town \& Country House \& Home Service Inc. v. Newberry, 3 N.Y.2d 554, 147 N.E.2d 724, 170 N.Y.S.2d 328 (1958); Boosing v. Dorman, 148 App. Div. 824, 133 N.Y.Supp. 910 (1912), aff'd mem., 210 N.Y. 529, 103 N.E. 1121 (1913).

4 Es., Colonial Laundries Inc. v. Henry, 48 R.I. 332, 138 Atl. 47 (1927); see also Smith v. Dravo Corp., 203 F.2d 369 (7th Cir. 1953); cf. Adolph Gottscho Inc. v. American Marking Corp., 35 N.J. Super. 333, 114 A.2d 19 (Ch. 1954), aff d, 18 N.J. 467, 114 A.2d 438 (1955).

- Es., Abalene Exterminating Co. v. Oser, 125 N.J. Eq. 329, 5 A.2d 738 (Ch. 1939); Morrisoa v. Woodbury, 105 Kan: 617, 185 Pac. 735 (1919).

so A term of art such as "trade secret" cannot readily be used as a test in the determination of liability because the particular term applies to a situation only when a court says that it does. Hence, various tests have been created to implement these terms, and in the 
labels does not appear to be found in the high-level employee cases. All that is there needed is a "plus" factor, whether or not the act involved falls within a particular category.

What the courts really appear to be doing in the high-level cases is to look at each case on an ad hoc basis in an attempt to ascertain whether or not there

development of these tests the courts appear to show concern for reasonableness of behavior in employer-employee relationships, even when the former employee had not been high in the corporate hierarchy.

In the customer list cases (see cases cited in notes 47-49 supra) this is often manifested by the court's concern over whether or not the list was written; e.g., Aetna Bldg. Maintenance Co. v. West, 39 Cal. 2d 198, 246 P.2d 11 (1952); Morrison v. Woodbury, 105 Kan. 617, 185 Pac. 735 (1919); Baton Rouge Cigarette Service v. Bloomenstiel, 88 So. 2d 742 (La. App. 1956); cf. Patterson v. Pollock, 84 Ohio App. 48984 N.E.2d 606 (1948); Addante v. Cinelli, 143 N.Y.S.2d 144 (Sup. Ct. 1955); contra, Alex Foods v. Metcalf, 137 Cal. App. 2d 415, 290 P.2d 648 (1956); George v. Burdusis, 21 Cal. 2d 153, 130 P.2d 399 (1942); se. 2 RESTATEMENT (SECOND), AGENCY \& 396(b) (1957); over whether or not a competitor could ascertain the names on the list without difficulty by mere perusal of a trade directory as a guide; e.g., Alex Foods v. Metcalfe, 137 Cal. App. 2d 415, 290 P.2d 646 (1955); California Intelligence Bureau v. Cunningham, 83 Cal. App. 2d 197, 188 P.2d 303 (1948); Avocado Sales Co. v. Wyse, 122 Cal. App. 627, 10 P.2d 485 (1932); National Tile Board Corp. v. Panelboard Mfg. Co., 27 N.J. Super 348, 99 A.2d 440 (App. Div. 1953); Abalene Exterminating Co. v. Oser, 125 N.J. Eq. 329, 5 A.2d 738 (Ch. 1939); People's Coat, Apron \& Towel Service Co. v. Light, 171 App. Div. 671, 157 N.Y. Supp. 15, aff'd as modified, 224 N.Y. 727, 121 N.E. 886 (1918); over whether or not the employee had learned of any special requirements of the customers during his employment; e.g., Delux Box Lunch \& Catering Service v. Black, 86 Cal. App. 2d 434, 194 P.2d 715 (1948) (concurring opinion); Dairy Dale Co. v. Azevedo, 211 Cal. 344, 295 Pac. 10 (1931); or over whether or not the list had been compiled at great expense or effort on the part of the employer; e.g., California Intelligence Bureau v. Cunningham, 83 Cal. App. 2d 197, 188 P.2d 303 (1948); Town \& Country House \& Home Service, Inc. v. Newberry, 3 N.Y.2d 554, 147 N.E.2d 724, 170 N.Y.S.2d 383 (1958).

It might seem that these distinctions are examples of judicial hairsplitting. Yet they are necessary if there is to be a proper balancing of the various interests. If a businessman has gone to great expense to develop a list of customers, where the names of the customers and their desires are not readily ascertainable, it is unreasonable for one of his employes to purloin such a list to his detriment; conversely, it is not unreasonable for the entrepreneur to seek legal sanctions against such an act. If, however, the contents of such a list can easily be ascertained by anyone possessing normal perception, an employee should be able to solicit the patronage of the customers of his former employer with impunity. To be consistent, this rule should not apply even where the expense of development of the list was great, if it was needless. To hold otherwise would deny the proposition that an employer has "no vested and indefeasible right to monopolize customers." Corica v. Ragen, 140 F.2d 496, 498 (7th Cir. 1944). See note 54 infra and accompanying text.

Similarly, the courts' concern for reasonableness is manifested by their allowing an employe to discuss business with a customer of his former employer, on his invitation, and even to accept proffered patronage, where he would not be allowed to solicit such patronage. E.g., Aetna Bldg. Maintenance Co. v. West, 39.Cal. 2d 198, 204, 246 P.2d 11, 15 (1952). The courts are willing to distinguish between acceptance and solicitation in order to achieve their goal of fairness to all parties.

The judicial handling of cases involving trade secrets also supports the assertion that the courts are in effect concerned with the reasonableness of questioned conduct. E.g., Kelite Corp. v. Khem Chemicals, 162 F.Supp. 332 (N.D. Ill. 1958) (chemical formulas); National Welding Equip. v. Hammon Precision Equip. Co., 165 F.Supp. 788 (N.D. Cal. 1958) (pressure regulators); Carter Prod. v. Colgate-Palmolive Co., 130 F. Supp. 557 (D. Md. 1955), aff'd, 169 F.2d 275 (4th Cir), cert. denied, 352 U.S. 843 (1956) (shaving cream formula); Julius 
is need for judicial interference "to promote honest and fair dealing ... [and to] protect not rights of the public but the rights and property of individuals." 31

In effect the courts are looking at the reasonableness of the employee's behavior vis-à-vis the relationship with his former employer. The converse of this is also true, i.e., that the relief sought by the former employer must be

[Footnote 50 continued from p. 349]

Hyman \& Co. v. Velsicol Corp., 123 Colo. 563, 233 P.2d 977 (1951) (insecticide formula); Junker v. Plummer, 320 Mass. 76, 67 N.E.2d 667 (1946) (shoe upper combining process); Adolph Gottscho, Inc. v. American Marking Corp., 35 N.J. Super. 333, 114 A.2d 19 (Ch. 1954), aff'd, 18 N.J. 467, 114 A.2d 438 (1955) (package marking process); Sun Dial Corp. v. Rideout, 25 N.J. Super. 591, 96 A.2d 788 (Ch. 1953), rev'd, 29 N.J. Super. 361, 102 A.2d 90, aff'd, 16 N.J. 252, 108 A.2d 442 (1954) (photographic process for marking precision dials); Boost Co. v. Faunce, 13 N.J. Super. 63, 80 A.2d 246 (Ch. 1951), aff'd, 17 N.J. Super. 458, 86 A.2d 283 (App. Div. 1952) (soft drink formula); Black v. Berstein, 152 N.Y.S.2d 655 (Sup. Ct. 1956) (optically compensated lens system); Perfect Measuring Tape Co. v. Notheis, 93 Ohio App. 507, 114 N.E.2d 149 (1953) (tape manufacturing process); Welex Jet Service, Inc. v. Owen, 325 S.W.2d 856 (Tex. Civ. Ct. App. 1959) (oil well drilling process); cf. Sasser y. Senco Products, Inc., 242 F.2d 565 (6th Cir. 1957). An example of this is the rule that an item, be it a formula or process of production, will not be protected as a trade secret if it is generally known by the industry. See, e.g., Junker v. Plummer, 320 Mass. 76, 67 N.E.2d 667 (1946). However, this does not mean that "absolute secrecy [of the process] is ... required ...." It is sufficient if there is a qualified secrecy vis-a-vis the industry. Sun Dial Corp. v. Rideout, 29 N.J. Super 361, 368, 102 A.2d 90, 94 (App. Div. 1954). See also Vulcan Detinning Co. v. American Can Co., 72 N.J. Eq. 387, 67 Atl. 339 (E. \& A. 1907); Richard M. Krause, Inc. v. Gardner, 99 N.Y.S.2d 592 (Sup. Ct. 1950); EluIS, Trade SECreTs $\$ 820,22$ (1953). This limitation reveals an implicit preoccupation with reasonableness. If it were not for such a limitation an employer could claim that any formula or process was a trade secret and hence deserving of judicial protection. If this were allowed, it would, in effect, preclude any of his employees from seeking other jobs within the industry. See, e.g., Bourns v. Edcliff Instruments, 125 F. Supp. 503, 508 (S.D. Cal. 1954). Similarly, the courts have denied injunctive relief where an employer is attempting to prevent a former employee from using the "general" skills and knowledge necessarily acquired in the course of employment. See, e.g., Safeway Stores v. Wilcox, 220 F.2d 661, 665 (10th Cir. 1955); Progressive Eng'r, Inc. v. Machinecraft, Inc., 169 F. Supp. 291, 298 (D. Mass. 1959); National Welding Equip. v. Hammon Precision Equip. Co., 165 F. Supp. 788, 796 (N.D. Cal. 1958); cf. Town \& Country House \& Home Service, Inc. v. Newberry, 3 N.Y.2d 554, 147 N.E.2d 724, 170 N.Y.S.2d 328 (1958); but see Carter Prods. v. Colgate-Palmolive Co., 130 F. Supp. 557, 578-79 (D. Md. 1955), aff'd, 169 F.2d 275 (4th Cir.), cert. denied, 352 U.S. 843 (1956). A particularly vivid example of the limits placed on a businessman seeking protection of a process is where the process was discovered fairly, i.e., by independent research. In such a case, the courts have refused to grant the plaintiff his injunction. See Boost Co. v. Faunce, 13 N.J. Super, 63, 86 A.2d 246 (Ch. 1951), aff d, 17 N.J. Super. 458, 86 A.2d 283 (App. Div. 1952); see also Eulis, supra, $\S \S 18,24$; $c f$. Wexler v. Greenberg, 399 Pa. 569, 160 A.2d 430 (1960). When the item possesses the requisite qualities of patentability, however, the courts find it reasonable to impose sanctions in favor of the holder of the patent. See generally ELLIS, supra, \$\$ 139-64.

The same judicial tendency is manifested in cases concerning restrictive covenants, both those not to compete after the termination of the employment, e.g., Morris v. Harris, 127 Cal. App. 2d 476, 274 P.2d 22 (1954); Harry Livingston, Inc. v. Macher, 30 Del. Ch. 94, 54 A. 2d 169 (Ch. 1947); Donahue v. Permacel Tape Corp., 234 Ind. 398, 127 N.E.2d 235 (1955); Baton Rouge Cigarette Serv. v. Bloomensteil, 88 So. 2d 742 (La. App. 1956); Abalene Ex-

[Footnote 50 continued on p. 351

51 Callmann, op. cit. supra note $15, \$ 3$ at 27. 
reasonable. If this is not done, it would be difficult, if not impossible, to have a proper balancing of the equities between the rights of the employer on the one hand and the employee on the other.52 An unreasonable act by either party to the employment relationship results in a corresponding abrogation of the other party's rights. It ought to be pointed out that, as far as the employee is concerned, the question of reasonableness arises in the context of a fiduciary relationship, rather than in the context of an ordinary business relationship; where the participants are dealing at "arm's length."

Essentially, the question is how much latitude of conduct will be allowed an employee if he decides to compete with his former employer. Two conflicting public policies are apparent. On the one hand there is the deeply imbedded tradition that favors the protection of a person's property interest in his business from unfair competition. What a person has labored for should be protected from wrongs by others. 53 On the other hand there is the equally strong, if not stronger policy which favors free competition in the economic sphere of our society. As a corollary a person has the right to improve his socio-economic status, even if the resulting effect is somewhat detrimental to the business interest of his former employer. 54 It is necessary that there be a

[Footnote 50 continued from p. 350]

terminating Co. v. Oser, 125 N.J. Eq. 329, 5 A.2d 738 (Ch. 1939); National Starch Prods., Inc. v. Polymer Indus., Inc., 79 N.Y.S.2d 357 (App. Div. 1948); Arthur Murray Dance Studio v. Witter, 105 N.E.2d 685 (Ohio C.P. 1952); Briggs v. Butler, 140 Ohio St. 499, 45 N.E.2d 757 (1942); Morgan's Home Equip. Co. v. Martucci, 390 Pa. 618, 136 A.2d 838 (1957); Arkansas Dailies v. Dan, 36 Tenn. App. 663, 260 S.W.2d 200 (1953); see generally Carpenter, Validity of Contracts Not to Compete, 76 U. PA. L. REv. 224 (1928); Note, Protection of Customer Lists in New York, 1 SYRACUSE L. REv. 110 (1949); and those not to disclose or divulge trade secrets. See, e.g., Sarkes Tarzian, Inc. v. Audio Devices, Inc., 166 F. Supp. 250 (S.D. Cal. 1958); Donahue v. Permacel Tape Corp., 234 Ind. 398, 127 N.E.2d 235 (1955). The thrust of these decisions seems to be that while a person can contract away his competitive rights, he cannot contract himself into a state of economic servitude by subjecting himself to restrictions unreasonable as to time or place. See Harry Livingaton, Inc. v. Macher, 30 Del. Ch. 94, 54 A.2d 169, 173 (Ch. 1947); see generally Arthur Murray Dance Studio v. Witter, 105 N.E.2d 685 (Ohio C.P. 1952) and cases therein cited.

In deciding if a restrictive covenant should be enforced, the courts have uniformly held that the burden of proof is on the party seeking relief to show that he will suffer irreparable injury if the injunction is not granted. For an excellent survey of the authorities on this matter, see Arthur Murray Dance Studio v. Witter, supra at 691-712. This requirement is analogous to the employer's burden of proving secrecy in the trade secret cases. Inherent in this requirement seems to be a judicial awareness that an employer does have superior bargaining power compared with an employee, and that if this power is left unchecked it might be abused to the employee's detriment. See note 54 infra and accompanying text.

52 See note 55 infra.

53 See Eurus, op. cit. supra note 50, § 1 ; see generally id., \$\$ 1-2, 4-14 and cases cited therein.

54 "[A] former employee should not be restrained from competing with a former employer even though it may result in some injury to his former employer ...." Addante v. Cinelli, 143 N.Y.S.2d 244, 247 (Sup. Ct. 1955). See, e.g., Continental Car-Na-Var Corp. v. Moseley, $24 \mathrm{Cal} .2 \mathrm{~d} 104,148$ P.2d 9 (1944) (district manager of "wax" firm could solicit patronage of customers of former employer). 
balancing of the equities between these two rights, $s 5$ for if the former is carried to its extreme it will deprive a man of his right to earn a living; 56 while conversely, the latter right, if unchecked, would probably make a mockery of the fiduciary concept, with its concomitants of loyalty and fair play.

Within the context of this balancing of equities it is arguable that the courts should consider the prior acts of the employer as a possible justification for the conduct of the employee.57 These acts might either justify the employee's conduct or at least mitigate the degree of relief granted. In this way it is not necessary to say the employee is right or wrong. The dilemma of such an either-or proposition is softened by the flexibility of the remedy. This flexibility permits a remedy befitting the actual wrong suffered by the employer, even if his treatment of the employee cannot be impeached. ${ }^{58}$ Since it is clear that the courts will not protect an employer if the employee has merely become another competitor, 59 they should, if the employee has acted reprehensibly, protect the employer only as long as the competitive advantage resulting from the employee's behavior exists.

In analyzing the "plus" factors of Standard Brands, using the reasonableness criteria, it is necessary to look at the situation as it existed at the time of the initial formulation of the plans. It must be remembered that for the most part, Standard Brands is within the area between the extremes of clear liability and clear immunity from liability.60 The defendants claimed that Standard Brands had never shown any concern for their personal welfare or future.61 Their choice of means to rectify this situation would appear to be unreasonable, however. There was nothing to prevent them from taking the initiative and demonstrating to Standard Brands the legitimateness of their complaints. If the plaintiff had been approached on the matter, but had still shown no intercst, then the competitive plans would have been much more reasonable. Even if it is assumed that the preparations were generally reasonable,the copying of the blueprints of the necessary machinery was not. Such behavior

5s See, e.g., Continental Car-Na-Var v. Moseley, supra note 54, at 110, 148 P.2d at 12-13. See also EtLIS, op. cit. supra note $50, \$ 11$. See generally, Carpenter, Validity of Contracts Not to Compete, 76 U. PA. L. REv. 244, 253-56 (1928); McClain, Injunctive Relief Against Employees Using Confidential Information, 23 KY. L.J. 248, 255 (1935); Note, Equitable Protection of Trade Secrets, 23 Colum. L. Rev. 164, 166 (1923); Note, Protection of Customer Lists in New York, 1 SYRACUSE L. Rev. 110 (1949).

56 See Simons v. Fried, 302 N.Y. 323, 324-25, 98 N.E.2d 453, 456 (1951).

57 Such possible justification is seen in the treatment of the defendant employees in Standard Brands and in the behavioral lapses of the president in Duane Jones. See notes 21 and 31 supra and accompanying text.

58 For a particularly cogent discussion of the need for reasonable relief, see the dissenting opinion by Frank, J., in Franke v. Wiltscheck, 115 F.2d 493, 500 (2d Cir. 1953).

s9 See notes 28, 30 supra and accompanying text.

60 See text supra at pp. 344-45.

61 See note 21 supra. 
should not be condoned as reasonable even where there is no employment relationship involved.62 It would seem that the plaintiff's requested relief63 was reasonable in view of the disastrous effect of the defendant's acts on its business. 64

The defendants' conduct in Duane Jones was also unreasonable, although not as clearly so. The concern of the defendants, here, was even more legitimate than in Standard Brands, 65 because their present means of livelihood was threatened by Jones' behavior. For the most part, their conduct was not unconscionable in that they did first attempt to purchase Jones' interest in the agency. As in Standard Brands, the reasonable end drd not justify the means used. Here the defendants attempted to bargain with Jones with a "gun at his head." 66 Moreover, they solicited their accounts' patronage prior to the termination of their employment. The request for damages was reasonable in that. for all intents and purposes, the defendants had destroyed the agency's business. ${ }^{67}$ Since the verdict of $\$ 300,000$ was based on the proposed purchase price of the firm, it would also seem proper. 68

62 See Smith v. Dravo Corp., 203 F.2d 369.(7th Cir. 1953). In this case, the defendant was enjoined from competing with the plaintiff in the freight container business until the latter had become re-established in the industry. The defendant, by professing an interest in the purchase of plaintiff's business, had acquired (1) knowledge of his secret designs and plans for freight containers, and (2) lists of present and prospective customers. This information enabled the defendant to produce a similar container at lower cost, to the detriment of plaintiff's business. Even though the parties were dealing at arm's length, and even though the defendant could have acquired the desired information in a legitimate manner -e.g., by examining an existent container-the court held that in this particular instance the information had been divulged in confidence, and hence that the defendant could be enjoined. See also Franke v. Wiltscheck, 115 F. Supp. 28 (S.D.N.Y.), aff d., 209 F.2d 493 (2d Cir. 1953).

${ }^{63}$ See note 21 supra and accompanying text.

o4 See note 21 supra.

65 See note 21 supra and accompanying text.

66 Consider, for example, the preselling of the alternative plan to the firm's clients. See 306 N.Y. at 181, 118 N.E.2d at 241. But see Comment, 4 DUKE B.J. 16 (1954).

67 Within six weeks of the formal opening of the defendant agency it had in its employ seventy-one of the one hundred thirty-two persons formerly employed by Duane Jones Co. and had appropriated $\$ 4,500,000$ of its annual billings. 306 N.Y. at 184,117 N.E.2d at 243.

68 But see Comment, 22 U. CHI. L. Rev. 278, 286 (1954).

There is an interesting ramification in the law of unfair competition which was accented there. Because of the form of the action in Duane Jones, the case was tried before a jury. See note 33 supra. An injunction against the defendants in Duane Jones would not furnish the plaintiff agency with adequate relief. Since Duane Jones was practically out of business, the defendant's clients would merely switch their business to other advertising firms in the area. The plaintiff agency would not benefit thereby. Damages provided the only advantageous form of relief for Duane Jones. However, in the usual case the requested relief is an injunction, the motion for which is heard by a judge sitting without a jury. As a consequence, judges are forced to delimit reasonable behavior in regard to competitive preparations. This can be contrasted to the field of torts where the delimitation of reasonable behavior vis-à-vis negligence is considered to be within the special province of the jury. 
An obvious objection to this emphasis on "reasonable behavior" in the employer-employee context is that it is a vague term, giving little or no guidance to an employee desirous of competing with his employer without incurring liability for a breach of a fiduciary duty or for unfair competition. The best advice which can be given an ambitious high-level employee, who is charting a competitive course, is that he should bring all of life's experience to bear in attempting to determine whether or not society will consider his proposed conduct fair, while always remembering that he will be held to a higher standard than a person dealing at arm's length with an enterprise. Implicit here, as in the reasonable man doctrine in torts, is the requirement that the test be objective rather than subjective. In the words of Mr. Justice Cardozo, the parties and the courts must realize that:

Here, indeed, as so often in other branches of the law, the decisive distinctions are those of degree and not of kind. One struggles in vain for any verbal formula that will supply a ready touchstone. The standard set up $\ldots$ is not a rule of law; it is rather a way of life. Life in all its fullness must supply the answer to the riddie. 69

If there is a fault in this position, it is not in the law, but rather it is in the fallibility of man.

Probably the closest we can come to a "ready touchstone" is to advise an employee to follow the Golden Rule, while always remembering that "[the] subsequent transaction will be subjected to a vigorous examination to see that the former agent did not abuse his position of trust and influence, or in any way fail in his attitude as agent during the agency."70

60 Welch v. Helvering, 290 U.S. 111, 114-15 (1933).

70 Wight v. Brown, 77 Ga. App. 375, 378-79, 48 S.E.2d 784, 787 (1945).

It is not sufficient to say that decisions such as Standard Brands and Duane Jones are caveats to an employee not to take short cuts in the effecting of his desires. Certainly such decisions are caveats to employees, but the courts should be aware that a disgruntled employer may unjustifiably attempt to use them against the competition of his former highievel employees. 